\title{
Creative -Destruction: The Essence of Entrepreneurial Studies
}

\author{
Professor A. N. Maduegbuna \\ Tansian University, Umunya Anambra State, Nigeria.
}

\begin{abstract}
Creative-Destruction is a mirror of entrepreneurial model meant to revolutionize actions of business people. The paper tries to look into the origin of creative-destruction which was traceable to economists of the old, in their guest to study capitalism, socialism and democracy. They wanted to know how slack resources from organizations could be utilized to create wealth to the benefits of humanity. Upon the analyses of the works of Karl Marx and Schumpeter, as well as other classical economists, it was proved beyond doubt that so many countries have built on the theories of the economists to develop ideas, new innovations, inventiveness and creative ways of prosecuting government projects and businesses. As early as the beginning of Nineteen Century, the economists had propounded theories, laws and principles, governing economic activities based on their western education, showing that for entrepreneurial studies to succeed in transforming the world, education which is the driver of economic growth must be encouraged by the nations of the world.
\end{abstract}

Keywords: Creative-Destruction, Entrepreneurship, Creativity, Inventiveness and Innovation.

\section{Introduction:}

Creative-destruction, which is associated with entrepreneurship, surprisingly demystifies the complex net work of entrepreneurial activities. Schumpeter (1934) as quoted in Lado and Vozikis (2010) had described entrepreneurship (Innovative entrepreneurship) as the engine of "creative-destruction", because it often involves the introduction of something new and or unique- a new product, a new service package, a new process and, destruction because it also involves the complete abandonment or downgrading of something currently in use. In the words of Okafor, F.O (2010), the innovative entrepreneurship is cast in the mould of a rebel or a change agent; he aspires to develop something new, a new product, a new service package or a new production process which often renders the existing products or services less functional or even obsolete. From the foregoing, the entrepreneurship is contextually viewed from its creativity and effectiveness in bringing out new products in the society through researches and other empirical studies. It has features of chasing away products with built-in obsolescence, that is to say, tries to bring out a new innovation which is superior to what is in existence.

This paper sees capacity building in entrepreneurship as the force that empowers intellectual growth which contributes to the value generating process of a firm. The study of entrepreneurship brings into the fore the difference between entrepreneurship and intrapreneurship, meaning that entrepreneurship grows further through the agency of intrapreneurship which is the stock of knowledge possessed by organizations. The government which is the patent spirit of entrepreneurship should encourage entrepreneurial studies, so that whoever exhibits extraordinary skills could be protected through patents, copyrights and trademarks. In the words of Maduegbuna A.N. (2010), if public sector entrepreneurship is introduced into an economy, such an economy will witness efficient management of resources, devoid of corruption, due to the vision and strong principles of the managers who perform in line with the best international practices.

The Nigerian University System, in line with global practices, has fashioned out a curriculum and pedagogical approach towards entrepreneurial studies to ensure that graduates produced from the system are not only strong ICT complaint but also effective employers of labour. As the system sustains this vision on regular basis with effective monitoring, the country may be able to realize her dreams of becoming the 20th largest economies by 2020, because the per capita income, level of Gross Domestic Product (GDP) and market capitalization of the nation may be on the increase, which are some of the indices of economic growth.

In Nigeria for instance, the mantra of government is entrepreneurship but this experiment would be fully realized if government promotes entrepreneurship and inventiveness by populist policies, such as encouraging small scale industries, reducing high level of taxes and other disincentives. By this arrangement, a lot of people will go into establishment of their businesses and be proud owners of their business enterprises.

A graduate, for instance, who has a sense of owning a business, must be prepared to be his own boss and make his own business decisions. There is nothing as encouraging as graduates being placed in a situation where they try out their ideas and direct their energies into business activities as they see it. Entrepreneurial studies can easily lead to researches and generate a spirit of inventiveness among people running their businesses. The concept of entrepreneurship is to produce graduates who can become employers themselves and provide employment to a great number of people. The patent advantage of entrepreneurship is, not only that a 
lot of people will own their businesses but will also develop their talents and learn better ways of doing something.

In the words of Emma Ezenyilimba et al (2010), a cursory look at the civilized countries of the world reveals that they achieved development on the platform of entrepreneurship and ingenuity; given instances of United States of America(USA), Japan, China, Singapore, Britain, Germany, North Korea, to mention but a few, who all acquired civilization through entrepreneurial efforts. Ogundele (2000) cited by Ezenyilimba et-al (2010) defines an entrepreneur as the individual, who initiates and nurses to growth, a new and on-going business organization, where none existed before: he is an individual who successfully thinks or conceives of a new business concern, organizes or initiates action to start it and manages it through its initial problems and struggles for its survival. He creates necessary wealth by taking all measures that lead the organization to a state of stability and self-sustaining growth. In deed, going by remarks of researchers, entrepreneurs can scan environment, marshall resources and implement professional ideas.

\section{Positive Impact Of Entrepreneurship On Society}

According to Daniel Uche (2013), at the wake of unemployment in Nigeria, many young/fresh graduates, low income earners, artisans, unemployed persons, corps members and students, who have entrepreneurial drive have resorted to self employment generation through the establishment of micro enterprises. Many nations have embarked on well thought out plans to alleviate poverty; poverty being one of the critical and striking problems that ravaged many countries, and since necessity, they say, is the mother of inventions, many countries have done some exploits to solve their problems through micro enterprises. Micro enterprise which is on the rung ladder of business process, is obviously the agent of mobilization of resources from the grassroots, and could develop into full blown entrepreneurship. It is at the grassroots that people start conceiving the ides of establishing their businesses.

In Nigeria, the formal financial system provides services to less than $40 \%$ of the economically active population, while more than $60 \%$ are excluded from access to financial services and this percentage of exclusion is served by Micro Finance Institutions, such as money lenders, organized "susu" group, friends, relations and others. In Nigeria also for instance, there is an Association of Small Business of Nigeria ( ASBON) that caters for the interest of small scale businesses. According to the President of the Association, Egbesola Femi (2014), in venturing into entrepreneurship, you must prepare yourself to pass through some rough roads before you get to the smooth lane (Saturday Sun Newspaper, July 26). A country benefits heavily if a good percentage of the populace has mindset for entrepreneurship.

In the words of Egbesola Femi(2014), President of Association of Small Business of Nigeria :

I took time to study people who are really successful in what they do. I found out that these are people that are into entrepreneurship. That made me to adopt them as my mentors and aspire to be like them by succeeding in my own field of entrepreneurship.

However, any country that is serious in developing entrepreneurship must be prepared to be a moving spirit for that purpose, by providing enabling environment, such as steady power supply, formulation of good polices towards small scale industries; designation of Development Banks that could extend loans to entrepreneurs with minimum difficulties, in order to make business of entrepreneurship thrive. In Nigeria, the prospect of entrepreneurship is very high, given government rolling plans that can enhance entrepreneurship, such as Central Bank of Nigeria's (CBN) plan to earmark 200 billion naira to support Small and Medium Enterprises (SMEs) - Saturday Sun, Newspaper July 26, 2014. There are other government agencies that have been established for the purpose such as the National Enterprise Development Programme (NADEP), the National Industrial Revolution Programme (NIRP), who all form platform for assisting people who are into small businesses .

The government may also consider the advantages and contributions of entrepreneurship to the country by way of reduction of unemployment, through granting of loans to them by

Bank of Industry, without insisting on collateral and other stringent conditions. In the words of President of Small Business of Nigeria, Egbesola Femi (2014) to the Youth:

If you choose to continue hunting for white collar job, or you choose to work for somebody, at a point when your energy level drops, you would retire. And by that time, you would probably not have enough mental toughness and energy to groom your own venture. Many would want to start big, but my advice is to start now; start small and then grow big. Don't wait till you have all the millions in the world before you start.

We must have a mindset to start small; even Dangote, the richest black African, started small.

Many developed and developing countries have solved most of their economic problems through the establishment of Small and Medium Scale Industries. India and China, whose population had crossed a billion mark, keep coping with such a teeming population, due to a vast array of small and scale industries, helping to absorb unemployed school leavers. The United States of America (USA) has a "Small Business Administration" (SBA) which is backed by law to draw funds from government for establishment of small scale industries on 
presentation of well articulate plan to run a business that is socially desirable. In India and China, the micro financial institutions which Nigeria embraces now as veritable vehicles for economic development, had been in existence in those countries for more than 50 years ago, as obvious catalysts and sustainable solutions for alleviating global poverty. The two policy thrusts of the

government which every concerned country is looking up to, for solving critical problems are inflation and unemployment. If the two variables are being held in check, the economy is expected to be stable. When a good policy is formulated, the government will do well by enforcing its implementation, so that it will be socially beneficial but if good policy is not implemented which is what Nigeria as a nation is suffering from, it is as good as ordinary paper on which the policy is written or committed to writing.

\section{Entrepreneurship And Intrapreneurship.}

In Nigeria, many government establishments go under due to lack of intrapreneurship which is an intellectual capital possessed by organizations. Intrapreneurs are those who work for big or large organizations and who also develop new ideas and better ways of doing business for organizations. We talk of introducing public sector entrepreneurship, which will help to restore lives of public corporations. If entrepreneurs happen to offer their services for corporate bodies, they become, with little training, intrapreneurs who bubble over with ideas and innovations that can bring their ideas to bear on the rapid growth of organizations or companies. As the Regulatory Agencies, such as the National Universities Commission (NUC), Federal Ministry of Education, and others, have adopted the entrepreneurial curriculum for higher institutions of learning, the graduates coming out from Universities can adequately fit into Labour market, because a lot of them who may wish to work in various corporate bodies and government establishments can readily become intrapreneurs, who have a lot of ideas and creativity to make businesses of government flourish. There are factors that lead to crass neglect of government establishments; either the attitude of no man's business is exhibited in managing the establishments or lack of creativity in the ideas put to their management. Apart from creation of wealth which is ascribed to entrepreneurship, it has capacity of revolutionizing the system of doing things both in the private and public sectors of an economy. Sometimes, nationally or internationally, transfer of technology is a part of promoting entrepreneurship, from developed to developing countries. Intrapreneurs are already the stock of intellectual persons or experts organizations have and by agreement, they can be transferred from one department to another or from one country to another through bilateral arrangements or multilateral agreements.

An entrepreneur in the context of this discussion may be individual or group of individuals focused and committed to development of their businesses but Intrapreneurs are what organizations, by virtue of their training and retraining, have that produce intrinsic value or goodwill to those organizations. They produce ideas that enhance management acumen and strong principles of the experts managing them.

\section{Terminology Of Creative-Destruction}

According to Schumpeter (1934) cited by Leonidas Deliginnidis and Erik Noyes (2010), Creative-Destruction is the primary mechanism for economic development for societies and businesses. In their views, entrepreneurs are the dynamic figures who combine, or recombine, vital resources to serve emerging customer needs, thereby "creatively" destroying the pre-existing economic order. This phrase "creative destruction" is traceable to Schumpeter's works on capitalism, socialism and democracy. He looks at capitalists as those who have wealth and who can muster the required human, physical and financial resources to make things happen, by way of application of those resources to create new economic order. The resources will aid researches to give rise to new industries and wealth. When the resources are properly and maximally applied, they are capable of bringing into the markets, new products, new packages, new thinking (ideas), new market lines, that can chase away old and inferior products as well as obsolete equipment. The explosive growth by agency of the combination of the resources will destroy the pre-existing economic order. According to Schumpeter, entrepreneurs are heroic figures who, with uncommon insight, foresight and actions, fashion new innovations which allow for the creation of new industries and their constituent new markets.

In point of fact, going through Schumpeter's reasoning, it becomes obvious that entrepreneurs are not always interested in money but being engrossed in their mindset and looking at the world of business activities, they see opportunities where others see problems. Some organizations fail because their owners are only interested in money but successful owners of businesses (entrepreneurs) must have ideas and dreams which they want to realize in the process of their business and economic activities.

In the words of Leonidas Deligiannidis and Erik Noyes (2010) and building on Schumpeter's theory, the Industry Association of America (2009) was cited as the popular music industry in the United States of America, of the value of $\$ 5$ billion dollar a year industry, creating and selling in 13 broad, major markets. According to them, the industry was not born until the early 1950s during the musical innovations of such artists as Fats Domino, Little Richard and Elvis Presley. In their remarks, while the popular music industry is roughly two decades older than the personal computer industry, it is several decades younger than industries such as the 
Automotive Industry, the Commercial Aviation Industry and the Chemical Industry. Over 60 years and above, according to Deligiannidis and Noyes, the popular music industry has emerged as a social and economic force, creating new wealth for companies in the music business and new creative outlets for the artists serving in the industry.

The works of Schumpeter and analyses of Deligiannidis and Noyes (2010), were copiously used which will provide more accurate baseline for those workers, students and other individuals who want to go into entrepreneurship. In the study of innovative entrepreneurship, the term destruction leads to the new spirit of creation, given room to a universal principle that every creative act has its destructive consequence. In further example of creative-destruction, typewriter has disappeared almost completely with the advent of computer and this scenario has led to the collapse of organizations that produced typewriters whose prices have also fallen, in the wake of new productions and innovations. By extension, all those companies or organizations that benefited or made money out of companies which became obsolete, might not adapt to the new technologies, leading to retrenchment of workers and other accompanying hardships.

\section{Importance Of Entrepreneurship}

Entrepreneurship formed the platform of Schumpeter's economic theory from the beginning of the nineteen century, due to its strategic perspectives in changing society. In so far as people's tastes, preferences or attitude change at one time or the other, entrepreneurship is the solution to those changes due to its dynamic nature. If every body in the society thinks as an entrepreneur towards business activities, the Gross Domestic Product, (GDP) of such an economy; per capita income as well as Market Capitalization will be on the increase, as a part of indices for economic growth. The spirit of entrepreneurship, especially in Nigeria, will reduce corruption because of engagement of people in different business activities, as against white collar jobs where people nowadays perfect on how to loot government treasury due to monotony and repetitive nature of government activities.

According to Wikipedia, the free encyclopedia, entrepreneurship within an existing firm or large organization has been referred to as intrapreneurship and may include corporate ventures, where large entities spin off subsidiary organizations. Entrepreneurs are leaders willing to take risks and exercise initiatives, taking advantage of market opportunities by planning, organizing and employing resources, often by innovating new or improving the existing products. Based on Wikipedia postulations, an economy that has Intrapreneurs in most of its firms or organizations will obviously reap the benefits of their expertise.

In the words of Ibenta S.N (2005), becoming an entrepreneur is not so much about who you have beenbut how you do things from now on; it is a way of looking at the world, seeing opportunity where others see problem. It is also knowing how to use certain basic tools to achieve your goals. Going from this reasoning, it becomes clear that an entrepreneur is a committed business man whose belief sees him through in his business ventures. Most of them being experts abhor waste of resources. When people who are non-experts perform a piece of work, there is the tendency of high level of business risks, due to the trial and error methods in doing things. Societies gain when entrepreneurs manage businesses whether as intrepreneurs in bigger organizations or in private businesses as individuals.

\section{Criticisms Of Creative-Destruction}

Creative-Destruction has its own criticism due to temporary hardship it may create. Even though, it is a cycle which can constantly destroy old order and constantly create new order, many organizations may have a serious set back especially when they cannot immediately cope with the new improved technologies and skills of doing businesses. However, when the economy continues to experience new ideas, innovations and creativity, the situation, following a continually innovating economy, could generate opportunities for those who are attuned to participation in more creative and productive enterprises.

In some countries of the world, such as India, china, Japan etc. entrepreneurship has become a major driver of economic growth. In India, the society has witnessed a rapid economic growth due to government interest in entrepreneurship which has led so many people to develop their talents. Many universities in India have become centers of excellence, in science and technology, in addition to developing so many skills which lead to production of high yielding varieties in the production of grains and other crops. Few farmers in India, can produce what feeds millions of people with the development of intermediate technologies and other innovations and inventions, helping the country to withstand the teeming population which has crossed one billion people, in population

The criticism of creative-destruction, as a means of destructive tendency, is only in the short run when there is crisis as a result of retrenchment of people from their work places but such a situation also has countervailing effect which triggers off determination and commitment on the part of people who have mindset in entrepreneurship, leading to their success in business outlets. Due to high level of unemployment in Nigeria, a lot of school leavers have exploited many areas of interest in business, in such a way that many are regretting 
why information on new lines of business did not come to them in time. Many have, in the course of business process, discovered their talents which ordinarily would not have been noticed if they had joined white collar jobs after their graduation. Government, being a spirit of entrepreneurship, must encourage people by matching statement with concrete action of providing enabling environment through concession in tax policy to people who have evinced enough interest in entrepreneurship.

\section{Conclusion}

This treatise on "creative-destruction" which leads to demystifying the technical nature of the phrase, makes interesting reading, given historical perspective and strategic importance of the phrase in the economic theory. It was traceable to Karl Marx which was fine-tuned by Joseph Schumpeter in his theory of innovation and business cycle. Many nations of the world can build on this theory to sustain the tempo of new innovations and creativity in running business enterprises. Creative-Destruction is the plank and platform for the nations in evolving series of researches for meeting people's needs through policy initiatives.

\section{Recommendations}

In the USA, Congress has created the Small Business Administration (SBA) to meet the perceived gap in financing small scale industries. According to Ibenta(2005), in less than 10 years, there were about 700 of such Small Business Investment Companies (SBIC) which had given birth to several hundreds of thousands of dynamic small firms and businesses and created millions of employment opportunities in the United States of America (USA).

It has been repeated more often than not, in different discussions and literature, that inflation and unemployment are the two important policy thrusts of any government, therefore for countries to create a good governance and welfare package for the people, they must work hard to reduce inflationary rate and unemployment in order to create desirable social and economic order. The United States of America, which floats lottery business that attracts people from all races to the country, is able to sustain the teeming population of people flocking the country because of policy initiatives of the government in creating millions of employment, through robust entrepreneurship empowered by the country. With advent of Information and Communication Technology (ICT), the world has become a global village; therefore, cross-fertilization of ideas brings development among nations. The laws, especially in developing countries, are necessary to protect inventors and people with creative and innovative abilities, in order to sustain entrepreneurship on continuous basis.

In developing countries, youth policy is necessary to curtail alarming rate of crimes. Position of youths should be addressed; what each category of youths does after each level of academic attainment, to create future for them and sense of responsibility at early stage of their lives, which is synonymous with the phrase, "catching them young".

\section{References}

[1]. Daniel Uche (2013): Micro Enterprise Development in Nigeria, 'Focus on Fast Growing Micro Businesses' Nigeria, Limited Elftonclick.

[2]. Ezenyilimba E. et al (2010): Entrepreneurial marketing oriented curriculum and Nigeria's Economic Development, Awka, Faculty of Management Sciences, 2011 conference proceedings.

[3]. Egbesola Femi (2014): President of Small Business of Nigeria, encouraging youths in the county to embrace entrepreneurship.

[4]. Ibenta S.N (2005): Investment Analysis and Financial Management Strategy, Enugu, Institute of Development Studies, University of Nigeria, Enugu Campus.

[5]. Ibid PP 332 and 334

[6]. Lado and Vozikis (2010): Transfer of Technology to promote entrepreneurship in developing countries, an integration and proposed model, http/ www. questia. com/googlescholar. gst:jsessionid.

[7]. Leonidas Deligiannidis and Erik Noyes (2010): Visualizing Creative Destruction in Entrepreneurship Education, USA, deligiannidisIewit.edu, enoyes@babson.edu

[8]. Maduegbuna AN (2010) Entrepreneurial studies: New thinking in wealth creation, Journal of economics, India, http//www.Krepulishers.com.

[9]. Okafor F.O. (2010) Faculty conference theme, 'Capacity Building in Management and Entrepreneurship: platform of sustainable economic growth', Awka. Nnamdi Azikiwe University.

[10]. Schumpeter J.A (1934): the theory of economic development, London. Oxford University press.

[11]. Saturday Sun Newspaper July 26, 2014. www.sunnewsonline.com

[12]. Wikipedia, the free encyclopedia,(2010) for the magazine, see entrepreneur (magazine). 